\title{
An Ethnographic Inquiry! Conceptualizing the Integration Experiences of the Sudanese Refugee 'Lost Boys' in the Greater Kansas City Area using Assimilation Paradigms
}

\author{
Danvas Ogeto Mabeya \\ Southeast Community College Education Square (ESQ)1111OSt.,Ste112 Lincoln, Nebraska. 68508-3614 U.S.A
}

\begin{abstract}
This study investigates the integration process of the Sudanese 'Lost Boys' living in the greater Kansas City area. The 'Lost Boys' are Sudanese refugees who relocated to the United States assisted by the U.S. government as a result of intensely bloody and protracted warfare in their home country then known as Sudan The purpose of this diversity-oriented study, in which a multiple case study model is employed for collection of data from forty 'Boys' participating in this study, is to find the experiences of these "Boys' in Kansas after resettlement. The specific goal of the study is to understand the degree of integration achieved by these 'Boys' during their fourteen-plus years living in the U.S. The study uses semi-structured interviews to assess the degree of integration. An adjunct inquiry is finding what type of social aspects played a key role in enhancing their faster adjustment into American mainstream society.
\end{abstract}

Keywords: Refugees, Unaccompanied Minors, Legal adults, Assimilation, U.S Refugee Policies

\section{THE RESEARCH QUESTION}

This study narrows down on a prior dissertation study, on the refugee Sudanese 'Lost Boys' in the greater Kansas City Area, and addresses the following research problem and question: Why does a group of immigrant refugees with the similar cultural and group experiences end up having different experiences in the United States! What developments shaped the 'Lost Boys' experiences in America?

\section{U.S. TRADITION ON REFUGEES}

The United States "open door" policy of resettling refugees began at the close of World War II, which included the resettlement of unaccompanied minors from Indochina in the 1960s/70s. In the 1970s, the U.S. accepted 14,000 unaccompanied minors from Cuba through Operation Peter Pan (Bixler, 2005). Many of these Cuban minors, aged five to eighteen, were sent to the United States by parents fearing their children would be indoctrinated in communist schools. In the case of these minors, they arrived in the United States with the consent of their still-living family members (P.90). More recently in 2010, 53 "lost children" from Haiti were brought to the United States following a devastating earthquake. In contrast to the above two situations, about 3,800 'South Sudanese 'Lost Boys' were resettled in the United States in 2000 based on their ages unaccompanied by their parents or families. The International Rescue Committee through their director in (2014) stated that since most of the arriving Lost Boys were deemed to be over 18 and thus considered young adults, they did not qualify for foster care, "We place the older boys together in apartments to try to maintain the kind of support network that they developed throughout their difficult journey and while living in the Kakuma camp. Muhindi and Nyakato (2002) after interviews with some Lost Boys in Boston came with the following, "the resettlement interview procedure seems in the opinion of the Lost Boys to have been very fair because it began with the original lists of minors from Ethiopia as a qualifying first round. The older Sudanese say they found their names put up on the notice board and assumed that the community elders forwarded their names" (p.13). Most of these 'Boys' didn't know their birth dates and were randomly assigned an age (minors or legal adults) by the U.S. government/UN to facilitate their resettlement process (Messina \& Messina, 2007 II. 2). It emerged in this study the Boys' who did not know their ages were given January 1 as their birth date when physically examined in the refugee camps. The intention of randomly assigning them ages was to make them eligible to receive benefits under government programs for unaccompanied minors in the U.S. (Barry, 2000).

\section{THE 1980 REFUGEE ACT}

Established in 1980, this act was meant to ensure that refugees become self-sufficient as quickly as possible. The U.S. Homeland Security Act (P.L. 107-296), that was enacted by the U.S. Senate and House of 
Representatives in 2002, established a new status for refugee unaccompanied children under the term, "unaccompanied alien children" (UAC). To qualify under this act, one had to be less than 18 years, lack lawful immigration status, and by the time of arrival in the U.S. one should be without parents or guardians who would take care of that individual. This seems to contradict the Refugee Act of 1980, as stipulated in the Congressional Research Service (CRS) Report for Congress that aims state (1) to provide a uniform procedure for refugee admissions; and (2) to authorize federal assistance to resettle refugees and promote their selfsufficiency"(Bruno,2006).

\section{HYPOTHESIS}

The main hypothesis of this study is this: Did the resettlement process of the refugee 'Lost Boys' have significant problems that could have been avoided!

\section{PRIMARY FINDINGS: CONSEQUENCES OF ARBITRARY ASSIGNED AGE RESETTLEMENT}

The demographic age resettlement arrangements immediately raised unforeseen challenges. Whereas minors were placed under foster families where they received social and educational support, those resettled as legal adults had to secure employment immediately to fend for themselves; they were provided with apartments rent-free for three months but had to start paying rent thereafter. Acquisition of English language skills was primary to secure even a manual job in the U.S. Another challenge that emerged was the lack of previous work experience as most hadn't worked in Africa. School-aged children rarely work in Africa as the vast majority depended on their parents as providers. In contrast, U.S. children as young as sixteen years old are permitted to work. Orphaned and resettled in the U. S., they soon discovered that nothing was free. This point was driven home when legal adults were informed that as soon as they started working, they had to repay the purchase price of the airplane tickets which allowed them to leave Africa as well as certain medical expenses (Bixler, 2005). Some Boys found it necessary to work two or three jobs to pay their bills and tuition and to remit some money to family and friends back in Africa (Mabeya, 2011: P.116). Securing jobs, the Lost Boys needed to accrue substantial valued social capital in their new host country which they lacked from Africa. In contrast on a similar issue, Canada that hosts a number of refugees including unaccompanied minors handles such cases differently. For instance, Jonathan Nicola a South Sudanese was accused of violating the immigration Refugee Protection Act by lying about his age. He is believed to be 30 years, while his immigration documents indicate he is 17 years making him eligible for high school education in Canada (Scott, 2016. Business Insider). However, like the U.S, the issue of refugee ages remains a challenge to refugee receiving countries like Canada. But who are the refugee Sudanese 'Lost Boys'!

\section{HISTORICAL PERSPECTIVE OF SUDAN}

Sudan has continuously sustained civil wars amongst its demographic/religious/racial groups for over four decades since its independence from Great Britain in 1956. The war of 1983 triggered the exodus of the young southern Sudanese 'Boys' commonly known as the 'Lost Boys' Many South Sudanese refugees dream of one day returning back to what most termed as their 'motherland' (Sudan Tribune, BBC News, 2011/02). However, this dream was short lived. Before most could even set foot in their 'motherland', there emerged a major obstacle to their return. In December 2013, the newest country in the world plunged into yet another conflict between the Southerners (tribal/ethnic groups). This conflict has been termed a 'civil war' by some international monitoring agencies (The Economist, December 27, 2013). Once again hope was lost.

\section{START OF THE EPIC JOURNEY}

As indicated above, the road-map of this study goes back to events starting in the 1980s. In the late 1980's, more than 33,000 'Boys' were forced from their homes due to outbreaks of violence in southern Sudan. The Sudan (Islamic/Muslim) government attacked the rebels in the south, killing civilians and enslaving young girls. Young 'Boys', who had taken herds of cattle out to grazing fields, were forced to run for their lives. The journey of these young 'Boys', who managed to survive, begins with them migrating from Sudan. They joined together in small groups and made their way first to Ethiopia, back to Sudan, then to Kenya (Messina \& Messina, 2007 II. 2). The International Red Cross, which found them as they walked to Kenya, named them the 'Lost Boys'. They were named after the characters from the story about Peter Pan, because they were unaccompanied by their parents when they arrived. Furthermore, these 'Boys' didn't know whether their families were alive or dead. The phrase 'Lost Boys' was used to identify those who didn't know where their families were. The international agency, United Nations High Commission for Refugees (UNHCR), took them to the Kakuma refugee camps in northern Kenya. While at the refugee camps, these 'Boys' were housed, fed, medically treated, and modestly educated from primary to high school (Bixler, 2005). By the time they reached the refugee camps they had walked nearly 1,000 miles, and approximately 10,000 'Boys' of the original 33,000 
arrived in Kenya (Messina \& Messina, 2007 II. 2). It was here that they were prepared for the long journey of resettlement in the U.S.

\section{CONCEPTUALIZING 'LOST BOYS' RESETTLEMENT OLD AND NEW EXPERIENCES USING ASSIMILATION PARADIGMS}

Classical assimilation paradigm, a 1920s model with origins in the Chicago School, has been used by researchers to define integration or incorporation of immigrants in the United States for a long time. This paradigm presupposes that since the U.S. has a diverse culture, then it can better be understood as a "melting pot", where immigrants and majority groups follow a "straight-line" interaction and over time both groups become more familiar in terms of norms, values, behavior and characteristics. Park (1928), a proponent of classical assimilation paradigm, contends that people of diverse origin eventually end up acquiring enough "cultural solidarity" to sustain a group's survival in a new society or country. In other words, immigrants who have spent more time in a host country will show greater similarities to those of the host society than those newly arrived (Brown and Bean, 2006). In retrospect, the 1970's assimilation trajectory was seen as a process in which people of different racial, religious, and cultural backgrounds became more homogenous (Rodriguez, 2004). This is in as far as joining the working middle class America and adapted white Protestant values (Brown \& Bean, 2006). Rodriguez (2004) further asserts, it is a process by which the non-dominant group comes to share aspects of common dominant cultural traits, eventually acquire a common culture, and access to opportunities of social structure of a given society. He goes on to say once the process of assimilation starts, it becomes an irreversible assimilation process of the immigrant.

Contemporary scholars recognize the differences between the post-1965 waves of immigration and earlier immigration, in terms of both the composition of immigrant cohorts and the policy of reception. In terms of immigrant composition, some proponents have emphasized that the new immigrants are mostly from Asia, Latin America and Africa, therefore non-white, and their minority status may have an effect in their full integration into the white middle class community in the U.S. (Gans 1992; Portes and Rumbaut 1996, 2001; Portes and Zhou 1993; Zhou 1997a, 1997b)- Further, Brown \& Bean (2006) conclude that classic assimilation, that was commonly used in immigrant integration studies in the $20^{\text {th }}$ century, failed to elucidate why the civil rights movement arose among African Americans in the 1960s since the civil rights movement highlighted the racial disadvantages and persistence of racial/ethnic identities in America, referred to as "double consciousness" by Du bois (1967). More recently, the emergence of BlackLivesMatter in 2013 after Trayvon Martin's murder by George Zimmerman and subsequently his acquittal, still highlight problems with what protestors termed institutional racism thus challenging the classic assimilation (Tometi, 2015). In addition for the refugee Lost Boys, English language and their physical appearance which is very distinct from that of African Americans as some of them are distinctly slim and tall, in addition to their rich, dark skin color, I would say experienced what I will call "triple consciousness." That is being African, immigrant/refugee, and American by naturalization because of their distinct physical unique characteristics. This in one way or another affected the way they carried out their daily interactions and activities in America (Benjamin, 1991). The above examples and many others pose a challenge to classical assimilation (melting pot model) where different groups in American are to be blended together ending up embracing Anglo Saxon values (Americanized).

Therefore, it is imperative when studying new waves of immigrants into the United States from other parts of the world excluding Europe to apply new and relevant paradigms that will elucidate their integration processes other than classical assimilation. Gans (1992), a critic of classical assimilation, argues that immigrants cannot follow a straight-line assimilation because each immigrant possesses different social capital. Brown and Bean (2006) have also asserted that immigrant cohorts may take different directions when it comes to assimilation into their new host society. First, it depends on the level of human capital (education/skills) that immigrants bring with them by the time of arrival, second on the social/economic structure of the host society (policies). When social/economic structures (e.g. discrimination and jobs) are not in favor of immigrants this may slow or block the assimilation process of immigrants outright. Further, transportation, logistics, insurance, and medical expenses are also widely cited by refugees as obstacles to receiving healthcare (Miedema , Hamilton, and Easley, 2008).

\section{EMERGENT ASSIMILATION PARADIGMS}

Several assimilation paradigms have evolved since the mid-nineteenth century as immigration to the United States gained momentum (Zaretsky, Znaniecki \& William (1996). To understand the dynamism of the contemporary assimilation processes, let's first look into four major emerging paradigms of immigrant and ethnic-group integration: Structural Assimilation, Immigrant optimism hypothesis; Spatial assimilation, and Segmented-assimilation hypothesis as stipulated by Hirschman (2001), and Massey (1986). In order to untangle the outcomes and complexity of the integration of immigrants in the U.S., researcher Gordon (1964) gave an alternative paradigm of understanding immigrant integration processes than that of classical assimilation. He 
suggested that structural assimilation paradigm would be a better way of understanding the new wave immigrants and their integration processes in the U.S. Gordon argued that structural assimilation was the cornerstone of all other stages of assimilation. Structural assimilation according to him, involved the immigrant accessing and being accepted to join social cliques, clubs, and other societal major institutions such as developed urban schools. Portes and Zhou (1993) argue that blockage of such social institutions such as school, and employment can be a major barrier to immigrant assimilation leading to downward social mobility. A situation like this can lead to resistance to integration and assimilation by immigrants who can embrace a counter culture for survival in the host society such as joining gang groups or other criminal activities (Mabeya, 2013). Portes, Zhou (1993) and others contend it is important to identify such barriers and others so that they can be dealt with at an early stage to enhance smooth integration of immigrants. Once immigrants access open social structures (e.g. schools, jobs) and participate freely utilizing their talents and skills, then assimilation of immigrants is enhanced. How can the case of the Lost Boys inform existing immigration scholarship?

Immigrant optimism paradigm predicts that the second generation of immigrants (immigrants who came as young children) will have the best of both worlds because they will end up having the mastery of English language and growing up in American institutions and interacting with American students (Hirschman, 2001). From the 'Boys' themselves, we learn of their optimism relative to their future prospects in American society (living the American dream). Muhindi and Nyakato (2002) highlighted in their research that the 'Lost Boys' expectations in the United States after their resettlement was to find a safe environment, as opposed to the rough and dangerous one in Africa. They expected to move freely, and realize their dreams of education and professional careers. They also hoped to get a safe haven in which they could heal from extremely severe trauma in good neighborhoods (Bixler, 2005). What is it about the case of the Lost Boys that requires theoretical elaboration?

Spatial assimilation paradigm, as articulated by Massey (1986), demonstrates that cultural adaptation and socio-economic development by immigrants would enhance their relocation from highly concentrated city center enclaves to less ethnically scattered city suburbs. With their relocation to city suburbs, immigrants would acculturate more by integrating with American residents within the suburbs and even being beneficiaries of structural opportunities such as employment. Berger (2004) gives an example of Peter Nyarol Dut, who left Houston, Texas for Kansas because he was frustrated with trying to make ends meet financially and trying to get to school. He found it difficult to adjust to the urban environment in Houston. Dut thought the only reason he came to the United States was to go to school as indicated earlier by Muhindi and Nyakato (2002). Alba and Nee contend, "the model of spatial assimilation leads to the hypothesis that residential exposure to members of the racial/ethnic majority should increase in tandem with socioeconomic standing, acculturation as measured by proficiency in speaking the English language, and generational status" (Alba \& Nee 1997). So what are some of the challenges for new immigrants such as the Lost Boys?

Over the past 100 years, drastic changes have taken place in America as a host society for immigrants. New immigrants entering the United States recently are faced with a period when demand for unskilled or semiskilled labor that was in demand in the turn of the century enhanced by the manufacturing-based economy is diminished greatly. This has made it less favorable for integration of new unskilled immigrants into the labor market due to the transformation of American society into a service-based postindustrial economy (SuarezOrozco and Suarez-Orozco 2001; Zhou 1997a; Massey 1995; Fernandez-Kelly and Schauffler 1994; Portes and Zhou 1993; Gans 1992). The new American economy can be best described as the "hourglass" economy that mostly has demand for college-educated professionals at the top tier and low-paying unskilled-skilled service laborers at the lower cadre (split labor market) (Xie and Greenman, 2005). The split labor market theory refers to a difference in the price of labor between two or more groups of workers depending on their human capital (skills), holding constant their efficiency and productivity (Bonacich, 1972). This has prompted scholars such as Portes, Zhou (1993) and others to review the traditional assimilation paradigms that were used in the turn of the century to study European immigrants into America. These scholars came up with a proposal of a new paradigm "segmented assimilation" to study new waves of immigrants other than those from Europe. This paradigm presupposes the United States as a stratified and unequal society with different "segments" of society available to immigrant that facilitate their assimilation. Segmented-assimilation paradigm provides a window for understanding incorporation of immigrants into their new environment. This theory responds to the dynamic individualized assimilation trends since 1960 in terms of family structure, socio-economic status, and educational achievement among some immigrant cohorts (Waters, 1990; Gans, 1992; Skop, 2001). As Hirschman (2001) asserts, "rather than expecting a uniform successful adaptation with greater exposure to (longer residence) American society, the segmented-assimilation hypothesis predicts that adaptation is contingent on geographical location, education, social class of the family of origin, "race", and place of birth" (P.6). Further, "the segmented-assimilation interpretation is supported by case studies of particular immigrant/ethnic populations that have been able to utilize community resources to pursue a strategy of encouraging their children's socio-economic mobility, but supporting only selective acculturation to American 
society" (P.6). However, Portes, Zhou (1993) and others caution for those immigrants who remain adamant and want to preserve their culture and traditions through social networks of the individual's own community, in most cases vie for resources (manual jobs) rather than first acquiring vital social capital (skills). This scenario can result from low self-esteem, especially if the immigrant is not able to communicate fluently with an employer and co-workers.

\section{INSTRUMENTS AND PROCEDUREMETHOD}

I opted to use qualitative research methods in this study because, rather than seeking validation, this study seeks to retain the rich original data in detail. In this study, purely quantitative methods were unlikely to elucidate the raw primary data necessary to address the research problem. Although both qualitative and quantitative studies seek to explain causal relationships, the latter are more variable-centered than the former. Because this study is based on open-ended questions, it makes sense to apply qualitative research tools. Furthermore, it is hoped that an interested quantitative researcher will be able to take the conceptual tools developed in this study and apply them to isolate relevant variables in future research.

\section{THE STUDY LOCATION AND DATA COLLECTION AGENDA}

This study is applies a case study model which provides the methodology for collection of data from randomly selected participants (Yin, 1994). The study employs an information-oriented sampling technique (snowball) in which the participants were allowed to refer or name their friends or other individuals in the population as potential interviewees (Patton, 1990). This technique enabled me to get 40 participants. Data used in this study was collected on July 25, 2009 from the participating Sudanese 'Lost Boys' in the greater Kansas City area. Primary investigation with the 'Lost Boys' participating in the study indicated that there were about 100 'Lost Boys' living in the greater Kansas City area (this number was not verified because official data was not available). All participants were 18 years and above at the time of their respective interviews. The interviews were conducted at the residence of one participant who was attending Johnson County Community College and who also acted as the liaison for the study, coordinating interviews held in his home. Data collection protocol for this study included in-depth and standard unstructured interviews, life stories, participant observation, informal conversation, and spending time with the 'Lost Boys'. This study drew from Ager and Strang's demographic and cultural/ethnographic criteria in examining key human development indicators to elucidate the relative degree of assimilation of each participant Lost Boy since their resettlement in 2000 (see Ager \& Strang, 2004: 3), The interviews were conducted face-to-face in English, while being recorded (later transcribed and analyzed). Doing face to face interviews allowed for the collection of observational data, such as facial expressions. Each interview ranged from half an hour to over two hours, with the majority being around an hour and a half. Although using an interview schedule, this study was flexible enough to allow the participants' time to reflect and then answer (not rushing their responses). Though some participants did not respond to all questions posited to them, it still remained important to make sure that further information was harnessed by making follow ups at the end of the interview. Since the study used open ended questions, it took a two-way communication where the interviewee asked for more relevant information when needed. The same questions were asked repeatedly to each participant and a saturation (reliability) point was reached at 40 face-to-face interviews, thus prompting an end of the interview process.

\section{DATA ANALYSIS}

Data for the study was analyzed by employing a thematic (discrete) system in which common responses from the data were identified (thematic system protects the confidentiality of individual participants as opposed to presenting individual cases (names). I interpreted and subsequently analyzed responses to each question. Interview data transcripts were subjected to full analysis with a categorization system derived based on thematic propositions allowing sub-units to emerge from the analysis and subsequent evaluation of each question asked. As stated by Eisenhardt (1989), if all participants or most participants provide similar results then there exists substantial support for the development of a preliminary theory that describes the phenomena. The common responses that emerged reflect major indicators of integration and/or marginalization, as well as the impact of the American society on the participating 'Lost Boys'. The common responses thus become the major themes of this study. Three major themes emerged during this study and recurred among nearly all participants from the above eleven categories mentioned earlier. These themes are: Human capital (Education), Jobs/Economic Empowerment, and, Naturalization/Citizenship. Participants are categorized into three groups depending on the social capital they possessed by the time of the interviews relative to each of the above themes. 


\section{RESULTS: LAYING DOWN THE THREE MAJOR THEMES HUMAN CAPITAL (EDUCATION)}

Education is viewed as crucial to successful living and is highly valued as a cultural core capital in the U.S., while it has been given low priority in countries such as southern Sudan (Franklin, 2002). For instance Brophy asserts that, "the education system in Southern Sudan has always been under resourced" (Brophy 2003 : p. 2). The South Sudanese culture puts high value in rearing of animals over western education. More so, for a long time the Sudanese government under resourced education in the south fearing socially, structural, and politically empowering the South (Brophy 2003: p. 2). Indeed it is impossible to overstate the importance of education as a social capital especially in Africa. The 'Lost Boys' were acutely aware that education in the U.S. was the primary means of securing a good paying job. Academic qualification was partly a criterion used for resettlement in the U. S. by recruitment and resettlement agents. It enhances individual integration (i.e. getting a job) that leads to self-sufficiency" (Bruno, 2006). The first group was comprised of 'Lost Boys' resettled in the U.S. with some education, but not instructed in English while they were in Africa. Acquiring proficiency in the English language is a 'vital capital' in the U.S. for immigrants. It not only enhances integration, but is a necessary tool for securing a job. With the help of resettlement agencies, this group was placed in foster care and enrolled in schools as they were identified as minors according to U.S. laws (18 years or less). The second group arrived in the U.S. without any English language skills, but was expected to work upon arrival in the U.S. because they were considered to be legal adults under U.S. law. The third group consists of 'Lost Boys' who arrived in the U.S. with elementary or high school education. While very few participants attended school in Sudan, all the participants in the third group received some education at refugee camps in Ethiopia or Kenya where they studied Arabic or English, respectively. Once resettled in the U.S., some in this group pursued further education while others looked for jobs and began working.

The first group: Eight participants were classified as minors upon their arrival in the U.S. and were subsequently placed in foster care. Five out of the eight had acquired some form of education in the refugee camps in Africa. More so, residing with foster families gave them an early opportunity for acculturation. For instance, foster families assisted them in improving their proficiency in English, paying tuition, provided housing, and helped them with other daily living expenses. In American schools, they learned to discard capital that was not useful (e.g. holding hands that could lead to discrimination from American students and potential employees mistakening them to be gay), and replaced it with higher-valued capital in the U.S. like keeping time, being efficient, and becoming successful. They also learned to maintain high levels of hygiene (i.e. brushing teeth, wearing deodorant, and disposing of trash in designated places only). The following participant stunned me with his level of language proficiency:

I did get support from foster families, yes I did. They would take me to school; take me to my ummm....., like if I had to run they would come and pick me up or drop me off until I had my car. And they actually gave me my third car, it was a Chevy Malibu '98. It was a very nice car and they paid for it till it was done. I am now independent...it's not like I need help from them anymore. I'm living on my own

The second group: Eight participants in this study, considered legal adults, had not acquired English language skills prior to resettling in the U.S. This group of 'Lost Boys' went through the refugee camps in Egypt and was instructed solely in Arabic. This group faced great challenges when trying to learn English, obtain work, and integrating with Americans and other African immigrants because they didn't share a common language. They felt isolated from the rest of mainstream American society.

At the time of this study, nearly all the 'Lost Boys' lacking significant proficiency in English were enrolled in English as a Second Language (ESL) courses in Kansas City. With some hard work in their studies with the English language, they hoped not only to communicate with Americans, but also with other nationalities present in the U.S. The following participant described great challenges when trying to speak English proficiently: Yea, it is difficult to get job because people from Kansas don't trust you. Some people, they don't need somebody who don't know English. That one is difficult. They are good people but problem is English. You don't know how to speak good English, you don't want to write good English, some people don't trust you. That one is difficult.

The third group: Twenty-four participants, considered legal adults, went through the Kenyan refugee camps of Kakuma and had received English instruction in both elementary and high school subjects. This group of 'Lost Boys' joined institutions of higher learning in Kansas City after resettling in the U.S. Some of them have graduated from a two-year program of study and were working, although they looked forward to furthering their education as one participant explained:You know what, whenever you have a higher level of education, it is 
almost guaranteed will have good living standards, having a house or raising a family, helping those back home. This is the important things that come with having high education level. That is how I look at it

\section{$\underline{\text { Summary }}$}

Nearly all participants in this section indicated ten years after arriving in the United States, they did not receive any educational support from the United States government, religious organizations (the church), or other public organizations. This participant confirms:

In Africa, we 'Lost Boys' used to receive everything from the United Nations and other western countries including the United States. But after resettling here, we received some assistance and then they cut it off after six months. We are now independent and working hard to support ourselves and paying bills. In America you can die if you don't work because no one cares. But we the 'Lost Boys' care for one another when we have problems

They worked and they attended school, paid their own tuition and education-related expenses. Those who had become U. S. citizens or permanent residents had the advantage of being able to apply for and secure federal student loans, as do many other American students. Some 'Boys' said they had attained partial scholarships to help them. More so, those that were placed in foster families had an advantage because their respective foster families helped pay some of the educational expenses, a privilege not available to legal adults.

\section{JOBS (ECONOMIC EMPOWERMENT)}

For the 'Lost Boys' and other groups of refugees, economic empowerment can only be attained through employment. Securing a job for most foreigners in the U.S. requires complex networking with Americans and established foreigners living in the U.S. According to Halpern's report prepared for the U.S. Department of Health and Human Services (see also U.S. Refugee Act of 1980), economic self-sufficiency is very important for successful resettlement of refugees (Halpern, 2008). McKinnon asserts the resettlement program for the 'Lost Boys' in the U.S. was one of the most successful ever in U.S. history, given that nearly all the 'Lost Boys' of legal age were employed after resettlement (McKinnon, 2008). The ORR published the employment percentage of the 'Lost Boys' at 85\%, whereas that rate was 55\% for other refugees in the U.S. in 2003 (ORR, 2003). Moreover, the ORR report found economic opportunity, language, and education to be important in economic self-sufficiency

This section categorizes the participant refugee 'Lost Boys' into four groups relative to the major theme of employment. Participants in the first group were resettled as minors, were legally barred from working and instead were placed in foster care and taken to American schools. The second group was comprised of 'Boys' who were considered young adults upon arrival. The third group arrived in America with some skills and education accrued in Africa. The fourth group acquired employment experience and skills only after arrival in the U.S.

The first group: Due to their young ages and scarcity of employment opportunities, ten participants didn't work in Africa. Although they were sent out to the fields to look after family cattle, this wasn't generally considered a job, rather it was viewed as an obligation to the family, and these children were not paid. This group of 'Lost Boys' resettled in the U.S. under the legal care of foster families. These families received assistance from the government and other refugee agencies in support of resettlement programs including financial and food assistance, as well as tax breaks from state and federal government. These 'Boys' weren't allowed to work in the U.S. because they were considered minors according to U.S. laws. However, they attended school prior to attaining working age. At the time of this research, all 'Boys' in this category had become young adults, moved out of their respective foster family homes, and were living on their own or with other 'Lost Boys'. One participant said:

When I first came to the U.S., I was placed in a foster family in California. I was told I was a minor by resettlement agencies. I did not know my really age though they said my age was thirteen years. The foster family took care of me. They paid for my school. They were nice people. They let me play with their children. They bought me clothes, books, and food. I really felt at home. When I became nineteen years, they assisted me to get a job. I got a job in a store and wanted to start living alone. So I looked for my own apartment and moved out. Live in California was too expensive and so I had to relocate to Kansas City where I have friends and life here isn't very expensive

The second group: This group of eight 'Lost Boys' was young adults when they arrived in the U.S. They were required to start working immediately after resettlement; however, most of them possessed no working skills prior to their arrival since they lacked the opportunity to go to school in Africa. For those who managed to attend school, they were handicapped as they were instructed solely in Arabic in Egypt (most of these 'Boys' had not gone to school in Sudan) and spoke no English. This group had difficulty obtaining employment 
because they lacked work experience and English language proficiency. As a result, most of them could only secure temporary jobs as manual laborers. One participant (English not fluent) said:

I don't have a job in Africa. I did not go to school in Africa. I only took care of my family cattle. My parents had a lot of cattle. I think the number was one to seven thousand. My grandfather gave my dad a lot of them before he died. I like cattle a lot. Now that I am in the U.S., I have to be on my own. I have to pay my bills. I have to go to school and pay tuition. Man, it is a lot difficult here. I can't get a nice paying job because I don't speak good English. But one day when I speak good English I will get a good job

The third group: This group of fourteen participants didn't have work experience in Africa. Most of them went to school in Kenyan refugee camps, though they lacked work experience as job opportunities in refugee camps were limited. This group acquired working skills in the U.S. only after they arrived. This group did not have many problems getting simple manual jobs because they could speak English and most of them received on-site job training. Six of these participants worked in nursing homes and were already trained as certified nursing assistants (CNA). Here is what one participant said:

I did my high school in Kenya in the refugee camp of Kakuma. When I arrived in the U.S., I was advised that it was easy to get a good paying job at a nursing home but I had to have some training. So I took a three month course and graduated as a CNA. It was not hard for me to get a job because they need people to work in nursing homes. Many Americans don't like doing this job. I like it and it pays so well

The fourth group: This group of ten participants possessed some education and working skills accrued in Africa. McKinnon would identify the resettlement of the third group of participants as "successful" because they secured employment and enrolled in post-secondary educational programs (McKinnon (2008). Although their English wasn't perfect, they were able to learn American English, and as a result employers were ready to hire them. Some had work experience from their days in refugee camps in Africa. In addition, this group received educational instruction in the Kenyan refugee camps, where English was a part of the curriculum. It was easy for participants in this group to fill out an application for employment on their own. Some of them had already earned two-year degrees and were working. One participant described his work experience in Africa and in the U.S. in the following way (translation is word for word):

In the U.S it is difficulty here. You don't have job, that one is difficult because no friends to go to live with. People don't do that here because you can work and go to school and you go to do something good. You don't have job, that one is difficult. In Africa, you don't have job, it is good because some people don't care about money. Your friends, your uncles, your aunties can help you. You know. You eat food free, you sleep free. You know. That one is different here. It is a nice place. Everything is good. But if you don't have help, it is difficult. We agree. I don't have English to write application because somebody is busy and don't have time to fill my application. I don't have to do anything

\section{Summary}

The interviews revealed that education and fluency in English were very important in helping 'Lost Boys' secure jobs in the United States. Nearly all of the participants in this study had no work experience prior to coming to the United States. All participants indicated that employment was important in achieving economic self-sufficiency.

\section{CITIZENSHIP (NATURALIZATION)}

The Fourteenth Amendment of the United States Constitution provides the legal framework for individuals of foreign countries to be naturalized in the United States. In 1945, President Harry Truman signed a statement that allowed displaced people and refugees to be given priority over other immigrants (Woolley and Peters 1999). From that time, a number of acts have been passed by congress which stipulates refugee policies. The Refugee Act of 1980 allowed refugees to be accepted into the United States on humanitarian grounds for unlimited stay so long as the countries of origin were still in conflict or having problems. The act also removed the cap that allowed only refugees from Europe (anti-communist) to allow refugees from the rest of the world especially from Africa (Newland, 1995). After attaining the required federal residency period in the U.S., most refugees apply to become U.S. citizens by naturalization. In this section I categorize the participant refugee 'Lost Boys' into three Groups. The first group consists of those who had not become American citizens. The second group is those who had become U.S. permanent residents. The third group is naturalized citizens.

The first group: Fifteen participants had not become U.S. permanent residents or citizens and they cited different reasons as to why they hadn't done so. Among some of the reasons they gave were the costs of 
processing the application to change their status. Some said it was not their first priority because no one forced them to leave, while others said they had not met the required stay period for them to change status. However, everyone in this group indicated that they were eager to change their status in due time. They were aware of the benefits of becoming a permanent resident or U.S. citizen. All participants in this group were resettled as minors. One participant said:

I would have been long time ago but I was not able because I had a lot of financial problems. However I would like to become a citizen so that I can be able to fly to Africa and other places in the world. I don't want to go to Africa and then get stuck over there. I don't want to struggle coming back. I need to get my citizenship so that I can be a free man Several participants in this category indicated they had not visited Africa because they were afraid they would be prevented from re-entering the U.S. They heard from others who lived in the U.S. for a long time that their visas were not renewed and they were barred from America after visiting a family in Africa. So, citizenship could guarantee their ability to travel freely to and from Africa, and to obtain other benefits, such as bringing their families to the U.S.

The second group: Composed of fifteen participants, this group already successfully applied for and became permanent U.S. residents. They said life for them was a bit easier than when they were just refugees. They could get student loans, travel in and out of the U.S.

Man you need to understand what being a U.S. permanent resident is. Are you one or are you a citizen? Being a permanent resident is different from being a refugee. Refugees are treated like not really human beings. Now that I am a permanent resident I can do a lot of things like travelling in and out of the US, I can also claim unemployment if I don't have a job. I don't care if I don't vote because I don't like politics after all

The third group: This group had ten participants who had become U.S. citizens. They looked more relaxed and talked more freely than other 'Lost Boys'. They said they considered themselves like any other American. Among other things, they cited they could vote in federal elections like any American. While smiling one participant had this to say:

When I was living in Kakuma, there are those Americans who were working in the refugee camps. They were so proud of themselves. They put on everything American. I just felt like a very low class person as compared to them. Now that I am an American, when I travel to Africa, my friends in the refugee camps are jealous of me. I told them I am an American and I showed them an American passport (smile)

Nearly all participants said they intended to stay in the U.S. for a long time after becoming U.S. citizens, though many of them said they were willing to go to South Sudan to visit family and friends. Some were reluctant to answer this question. One said:

That is the same question senator Sam Brownback asked me when I met him 2007. I don't know how long I will stay here but at some time in my life I will go back to Sudan. For now I am here to stay What I found from these participants is that most of them did not care much about the responsibilities that went with American citizenship. Most of them said they did not want to serve in the jury, serve in the military, or even vote. This participant summarized and said what he looked forward to by saying:I did not become an American citizen by coming here to charge Americans. Americans gave me a chance to come over and live with them. That is why they gave me citizenship. I am proud of that. I am not going to send Americans to jail. That is the work of Americans who were born here. I don't even understand some of the American crimes. I also won't want to serve in the military. I run from war and I did not come here to go to war nor do I want to vote. I don't like politics at all. I just want a quiet life. Build myself and my family

\section{Summary}

Acquiring American citizenship has helped the 'Lost Boys' to access American welfare. It has enabled them to compete with Americans in the job market and admission into American mainstream society. They could also get loans. Most immigrants who are not either permanent residents or citizens cannot access social welfare including employment.

\section{ANALYSIS}

Finding a safe sanctuary, an education, and a job was utterly important to every participant Lost Boy in my study (Mabeya, 2015). These findings are supported by Muhindi and Nyakato's (2002) research, which underlined the expectations of the 'Lost Boys' finding a safe environment in the United States in which they could move freely, express themselves without fear, and realize their dreams of education. They also hoped to get well-paying jobs, which would enable them to build their socio-economic upward mobility (Bixler, 2005). 
By the time of this research, the participant 'Lost Boys' in Kansas had undergone more than a decade of transformation in the United States and had worked hard to achieve their goals as indicated in the three major themes of this study above. Their 'successful' integration process required both social and economic integration. In the face of incredible anomie, some of them had become proficient in English, acquired U.S. citizenship, found jobs, and coped with the violent loss of family members and familiar social structures and values. Education played a crucial role in acculturation and integration of these 'Boys'. Without education and language acquisition, the 'Boys' had little hope of securing desirable employment, financial stability and/or prosperity, or acceptance in American social groups. Employment helped elevate their status among Americans, education helped them get jobs thereby empowering them economically, and citizenship helped them gain admission into American mainstream society. Those who have acquired citizenship have obtained the right to vote, secure student loans, and the ability to freely travel in and out of the United States indicating structural assimilation which is the cornerstone of all stages of assimilation as articulated by Gordon (1964).

\section{SOCIOLOGICAL EXPLANATION OF ASSIMILATION PATTERNS OF THE LOST BOYS}

Despite the presence of anomie in each Lost Boy, challenges associated with successful living in the United States might be said to pale in comparison to the life and death situations faced by the 'Boys' in Africa. With time, those resettled as minors overtook those resettled as adults in their accumulation of social capital necessary for assimilation following the immigrant optimism paradigm. This Paradigm predicts immigrants who came as young children (minors) will have the best of both worlds because they will end up having the mastery of English language, growing up in American institutions, interacting with American foster families, and interacting with American students (Hirschman, 2001: 6). Those who have climbed the ladder of education have gained intellectual capital which they used to enter into desirable U. S. labor invoking the split labor market theory as stated by (Bonacich, 1972). Those minors who were placed in foster families were better integrated socially but were behind relative to employment, naturalization, and college education, let alone their retention of Sudanese culture as compared to the 'Boys' who settled as adults as predicted by immigrant optimism paradigm by Hirschman (2001: 6). The findings of this study suggest that one's age and the treatment of people by their legal age (minors/adults) can play an important role in shaping the kind of capital and opportunities made available to individuals. Portes and Zhou (1993) and others came up with a segmented assimilation framework in studying new waves of immigrants and their children. This paradigm elucidates advantages and disadvantages a group of immigrants can face in accessing opportunities in a new environment relating to contextual, structural, and cultural factors that bolster successful to unsuccessful assimilation of immigrants. Parks presupposes that when immigrants and majority groups follow a "straight-line" interaction, over time both groups become more familiar in terms of norms, values, behavior and characteristics of the host society. Eventually immigrants end up blending together with the indigenous population ending up embracing Anglo Saxon values or being Americanized in what he referred to as the 'melting pot'. An enhanced way of doing this is when immigrants end up relocating from highly concentrated city center enclaves to less ethnically scattered city suburbs. With relocation to city suburbs, immigrants would acculturate more by integrating with American citizens within the suburbs and even being beneficiaries of structural opportunities such as employment thus invoking Spatial assimilation as articulated by Massey (1986).

\section{CONCLUSION}

This study concludes that age-based disadvantage was evident in the case of the Lost Boys and was a major barrier to enhanced integration of the refugee 'Lost Boys' 'minor's vs legal adults'. The 'Boys' that were resettled as minors had advantages of immersion, since they were placed in foster families who acted as surrogate parents, thus aiding their faster assimilation. Those resettled as legal adults were left to look for jobs immediately after resettlement and fend for themselves. They did not have time to acculturate and learn important American cultural values, such as going to school and getting an education, which some did not get a chance to acquire from Africa. Maumbuko and Nyakato (2002) concluded in their study that the Sudanese refugees "should have been handled as a single package caseload for resettlement" (P.20). Bol Biong Bol (executive director of the Sudanese Community Association, a San Diego-based organization that helps refugees assimilate in America) explains: "The hard fact is that in the United States, Social Darwinism is still the operating principle. As time goes by, we will have some 'Lost Boys' who will be very successful, and we will have some people who will remain on the lower economic level, and we will have some people who will be frustrated" (Weddle, 2003 p. 11). Finally, the Lost Boys assimilation experiences in Kansas City area and elsewhere in the United States is a clear testimony that refugee resettlement programs need to be improved to further make refugee life better and more comfortable. Equal opportunity for all resettled refugees should be the key guiding policy. 


\section{REFERENCES}

[1] Ager, A., \& Strang, A. (2004). Indicators of integration: Final report. Edinburgh, Scotland: Queen Margaret University College. Retrieved from http://www.homeoffice.gov.uk/rds/pdfs04/dpr28.pdf

[2] Alba, Richard, Logan, John R \& Crowder K. (1997). "White Ethnic Neighborhoods and Assimilation: The Greater New York Region, 1980-1990,” Social Forces, 75:883-912.

[3] Alba, R. D., \& Nee, V. (1997). Remaking the American mainstream. Assimilation and contemporary immigration. Cambridge, MA: Harvard University Press.

[4] Barry, E. (2000). Sudan's Lost Boys find new home: Orphaned survivors of a savage civil war settling in Boston. Globe Staff. Retrieved from

ww.boston.com/news/local/articles/2000/12/03/sudans_lost_boys_find_new_home/Benjamin, Lois (1991). The Black Elite; Facing the Color Line in the Twilight of the Twentieth Century, Chicago: Helson-Hall

[5] Berger, L. (2004, November 5). Sudanese "Lost Boy" finds new life in suburban Kansas. Lawrence.com. Retrieved from http://www.lawrence.com/news/2004/nov/05/lostsudan/

[6] Bixler, M. (2005). The Lost Boys of Sudan: An American story of the refugee experience. Athens: The University of Georgia Press.

[7] Brophy, M. (2003). Progress to universal primary education in southern Sudan: A short country case study. In Gender and education for all: The leap to equality-Background paper prepared for the Education for All Global Monitoring Report 2003/4. Gender and Education for all: The Leap to Equality. Paris, France: UNESCO. Retrieved from

http://unesdoc.unesco.org/images/0014/001467/146755e.pdfBrown K. Susan, Bean D. Frank (2006). Assimilation Models, Old and New: Explaining a Long-Term Process. Retrieved from: http://www.migrationpolicy.org/article/assimilation-models-old-and- new-explaining-long-termprocess.

[8] Bruno, A. (2006, January 25). CRS Report for Congress: Refugee admissions and resettlement policy.Retrievedfromhttp://www.wrapsnet.org/LinkClick.aspx?fileticket=dR\%2FcVscHXNc\%3D\&;ta bid=180\&mid=605\&lan guage $=$ ar-IQ

[9] Dubois, W.E.B (1967). The Philadelphia Negro: A Social Study. New York: Schocken (orig. pub. 1899)

[10] Bonacich, Edna (October 1972). "A Theory of Ethnic Antagonism: The Split Labor Market". American Sociological Review. 37 (5)

[11] Eisenhardt, K. M. (1989). Building theories from case study research. Academy of Management Review, 14, 532-550.

[12] Gans, Herbert J. (1992). "Second-Generation Decline: Scenarios for the Economic and Ethnic Futures of the post-1965 American Immigrants.” Ethnic and Racial Studies 15(2): 173 - 192.

[13] Gordon, M. M. (1964). Assimilation in American Life: The Role of Race, Religion, and National Origins. New York: Oxford University Press.

[14] Halpern, P. (2008). Refugee economic self-sufficiency: An exploratory study of approaches used inOffice of Refugee Resettlement Programs (Report Prepared for U.S. Department of Healthand Human Services, Office of the Assistant Secretary for Planning and Evaluation). Retrieved from http://www.acf.hhs.gov/pro-grams/orr/policy/s107-08.htm

[15] Hirschman,Charles.(2001). “The Educational Enrollment of Immigrant Youth: A Test of the Segmented AssimilationHypothesis.” Demography 38(3): 317-336.

[16] Mabeya, D.O. (2015). Capital Matters: "Found" Social Capital of the Sudanese Refugee Lost Boys Living in Kansas City Area. SAGE Open. DOI: 10.1177/2158244015621955 Published December 2015. http://sgo.sagepub.com/content/spsgo/5/4/2158244015621955.full.pdf (2013).

[17] (2013). A case of Anomie! A sociological explanation of the Sudanese Lost Boys' copying experiences in the U.S. GSTF International Journal of Law and Social Sciences(JLSS), 2(2), 131. Retrieved from: dl6.globalstf.org/index.php/jlss/article/download/568/584

[18] _ (2011). Lost and found: Different integration patterns of the Sudanese Lost Boys living in Kansas City area after resettlement (Doctoral dissertation). Retrieved from http://gradworks.umi.com/34/58/3458420.html

[19] McKinnon Sara L. (2008). "Unsettling Resettlement: Problematizing 'Lost Boys of Sudan' Resettlement and Identity." Western Journal of Communications 72 (4): 397 - 414

[20] Massey, D.S. (1986). "The Settlement Process Among Mexican Migrants to the United States American Sociological Review 51: 670-85.

[21] Messina, J. J., \& Messina, C. M. (2007). Coping.org: Tools for coping with life's stressors; “The Lost Boys of Sudan" background history of the Lost Boys of Sudan. 
[22] Miedema, B., Hamilton, R., and Easley, J. (2008) "Climbing the walls. Structural barriers to accessing primary care for refugee newcomers in Canada." Canadian Family Physician. 54: 335-336. Accessed on 12 December 2016.

[23] Muhindi M. Martin and Nyakato Kiganzi. (2002). Integration of the Sudanese "Lost Boys" In Boston, Massachusetts USA.

[24] Newland Kathleen (1995). Impact of U.S. Refugee Policies on U.S. Foreign Policy: A case of the Tail Wagging the Dog? CARNEGIE CHAPTER IN TEITELBAUM, MICHAEL S. AND MYRON WEINER, EDS., THREATENED PEOPLES, THREATENED BORDERS: WORLD MIGRATION AND U.S. POLICY, NEW YORK: THE AMERICAN ASSEMBLY. Retrieve from http://www.carnegieendowment.org/publications/index.cfm?fa=view\&id=229

[25] Park, R.E. (1928). "Human Migration and the Marginal Man," American Journal of Sociology. 33:881 893.

[26] Patton, M. Q. (1990). Qualitative Evaluation and Research Methods (2nd ed.). Newbury Park, CA: Sage Publications, Inc.

[27] Portes, Alejandro, and Min Zhou (1993). "The New Second Generation: Segmented Assimilation and its Variants." Annals of the American academy of Political and Social Science 530: 74-96.

[28] Portes, Alejandro and Ruben G. Rumbaut. 1996. Immigrant America: A Portrait. Berkeley: University of California Press.

[29] Rodriguez Gregory (October 10, 2004) Assimilation Happens - Deal With It. Los Angeles Times. Retrieved from http://www.latinamericanstudies.org/latinos/assimilation.htm

[30] Scott Davis (Apr. 21, 2016). A Canadian high-school basketball star has been arrested and is accused of actually being 30 years old. Retrieved from: http://www.businessinsider.com/canadian-high-school-basketball-star-accused-of-being- 30-years-old2016-4

[31] Suarez-Orozco, Carola and Marcelo M. Suarez-Orozco (2001). Children of Immigration. Cambridge, MA: Harvard University Press.

[32] Sudan Tribune, BBC News (2011). Available: http://menasborders.blogspot.com/2011/02/albashir-accepts-southernsudan.html

[33] The Economist (2013, December 27). The descent into civil war. Retrieved from: http://www.economist.com/blogs/baobab/2013/12/south-sudan

[34] Tometi, Opal (2015) “Celebrating MLK Day: Reclaiming Our Movement Legacy,” Huffington Post Black Voices Blog, January 18, 2015, http://www.huffingtonpost.com/opal-tomet....

[35] U.S. Department of Health and Human Services (2003): Refugees in the United States. Annual

[36] ORR Reports to $\quad$ Congress-2003. $\quad$ Retrieved from http://www.acf.hhs.gov/programs/orr/data/01arc8.htm

[37] U.S. Refugee Act of 1980. Pub. L. 96-212. 94 Stat. 102. 17 March 1980. Print.

[38] Franklin,V.P. (2002). Introduction: Cultural Capital and African American Education. The Journal of African American History. Vol. 87, pp. 175-181

[39] Waters, Mary. (1990). Ethnic Options: Choosing Identities in America. Berkeley: University of California Press.

[40] Xie Yu and Greenman Emily (August 2005) Segmented Assimilation Theory: A Reformulation and Empirical Test. Population Studies Center Research Report 05-581. Retrieved from: http://www.psc.isr.umich.edu/pubs/pdf/rr05-581.pdf

[41] Weddle, D. (2003, January 5). What the Lost Boys of Sudan Found in America. Los Angeles Times. Retrieved from http://articles.latimes.com/2003/jan/05/magazine/tm-lostboys1

[42] Woolley, John T. and Peters, Gerhard. The American Presidency Project . Santa Barbara, CA. Retrieved from http://www.presidency.ucsb.edu/ws/?pid=12253 (02/10/2010).

[43] Yin, R. K. (1994). Case study research: Design and methods. Thousand Oaks, CA: Sage.

[44] Zaretsky, Eli; Znaniecki ,Florian; William I. Thomas (1996). "Introduction". The Polish Peasant in Europe and America: A Classic Work in Immigration History. University of Illinois Press. ISBN 978-0-252-06484-5.

[45] Zhou, Min. 1997a. "Segmented Assimilation: Issues, Controversies, and Recent Research on the New Second Generation." International Migration Review 31(4): 975-1008.

[46] Zhou, Min. 1997b. "Growing up American: The Challenge Confronting Immigrant Children and Children of Immigrants.” Annual Review of Sociology 23: 63-95. 